Supporting information

In Situ Formed $\mathrm{Pt}_{3}$ Ti Nanoparticles on a Two-Dimensional Transition Metal Carbide (MXene) Used as Efficient Catalysts for Hydrogen

Evolution Reactions

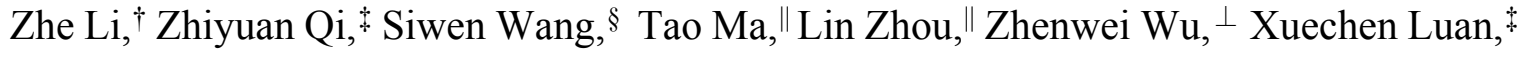

Fang-Yi Lin, ${ }^{\dagger}$ Minda Chen; Jeffrey T. Miller,$\perp$ Hongliang Xin, ${ }^{*}$ Wenyu Huang, ${ }^{*}$ and

Yue $\mathrm{Wu}^{*}$ 
Table of content

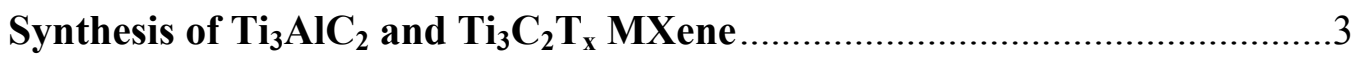

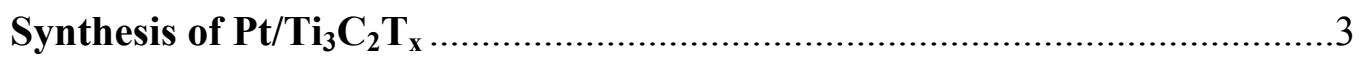

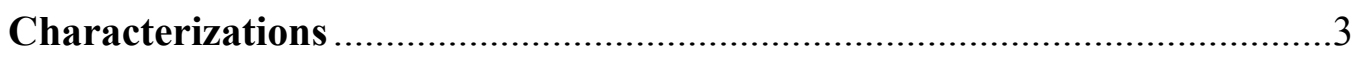

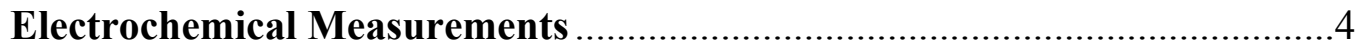

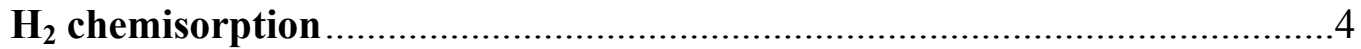

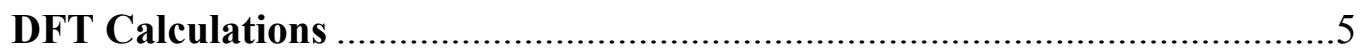

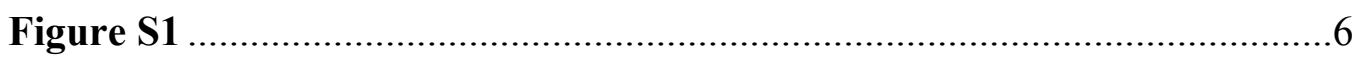

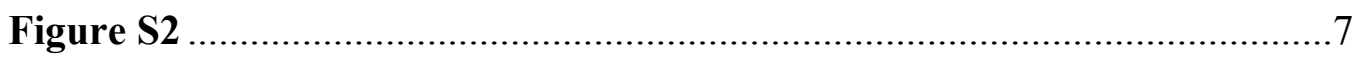

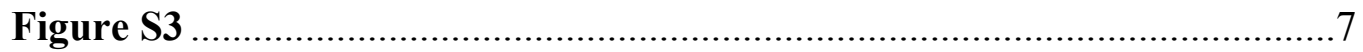

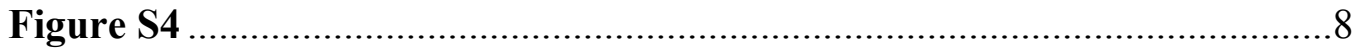

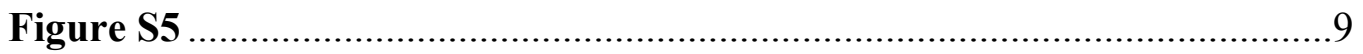

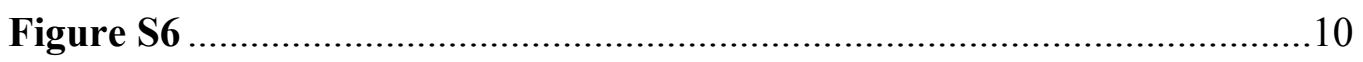

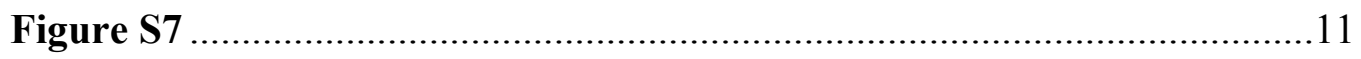

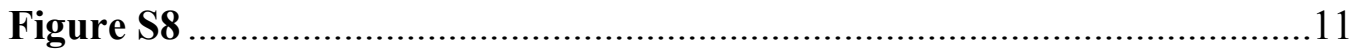

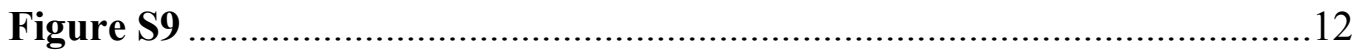

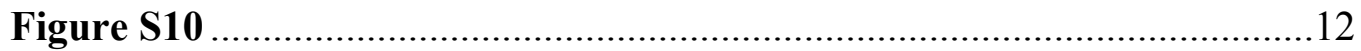

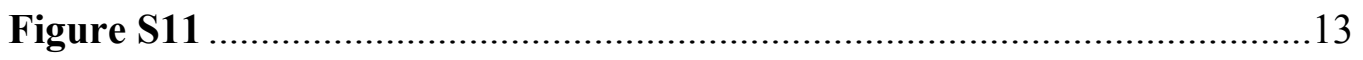

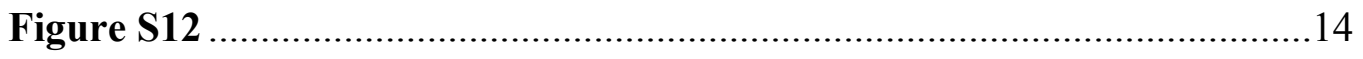

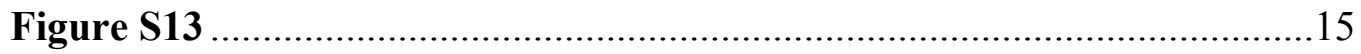

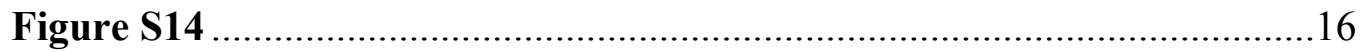

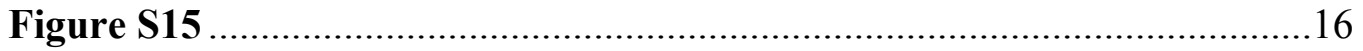

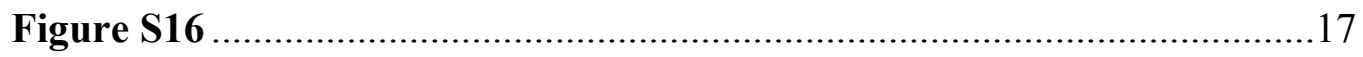

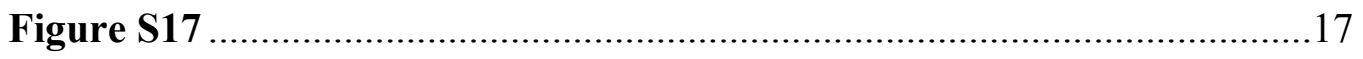

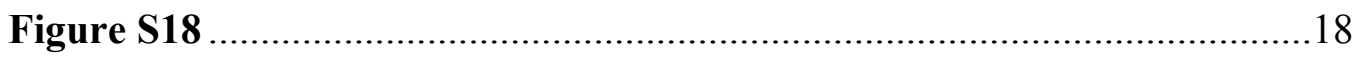

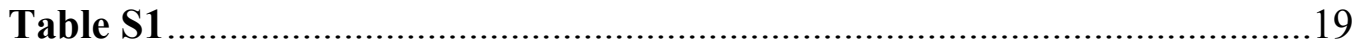

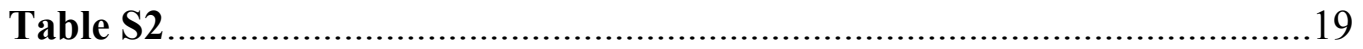

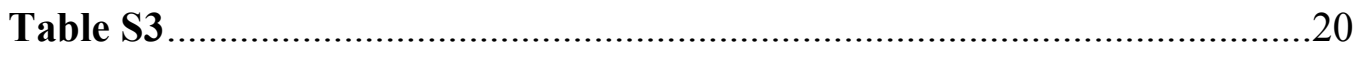

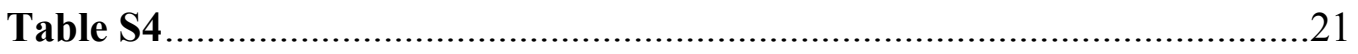

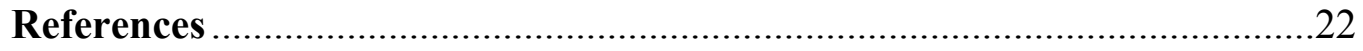




\section{Synthesis of $\mathrm{Ti}_{3} \mathrm{AlC}_{2}$ and $\mathrm{Ti}_{3} \mathrm{C}_{2} \mathrm{~T}_{\mathbf{x}} \mathrm{MXene}$}

The synthesis of $\mathrm{Ti}_{3} \mathrm{AlC}_{2}$ was achieved by spark plasma sintering (SPS). In details, commercial powders of titanium (II) hydride (Alfa Aesar, 99\%), aluminum (Alfa Aesar, 325 meshes, 99.5\%) and titanium (IV) carbide (Sigma Aldrich, 325 meshes, 98\%) were mixed in a molar ratio of $\mathrm{TiH}_{2} / \mathrm{Al} / \mathrm{TiC}=1: 1: 1.8$ in a graphite die coated with boron nitride $(\mathrm{BN})$. Excess $\mathrm{Al}$ and less than a full equivalent of $\mathrm{TiC}$ were added because a small portion of Al will be lost during high-temperature processing, and carbon deficiencies exist in most Al-containing MAX phases. Then, the material was loaded in a Fuji-211lx SPS system and sintered at $1350{ }^{\circ} \mathrm{C}$ under $30 \mathrm{MPa}$ for one hour. The resulting $\mathrm{Ti}_{3} \mathrm{AlC}_{2}$ was then pulverized and sieved through a 325-mesh screen.

The $\mathrm{Ti}_{3} \mathrm{AlC}_{2}$ powder was treated with $50 \% \mathrm{HF}$ at $35^{\circ} \mathrm{C}$ for 24 hours. The sample was then washed by deionized (DI) water until the $\mathrm{pH}$ reached $\sim 5$. The resulting powder was collected by centrifugation at $8900 \mathrm{rpm}$ and then dried under vacuum. The $\mathrm{Ti}_{3} \mathrm{C}_{2} \mathrm{~T}_{\mathrm{x}}$ was stored in a glove box filled with $\mathrm{N}_{2}$ for future use. Around $50 \mathrm{mg}$ of the as-synthesized $\mathrm{Ti}_{3} \mathrm{C}_{2} \mathrm{~T}_{\mathrm{x}}$ was dispersed in $50 \mathrm{ml}$ DI water. After bath sonication for $30 \mathrm{~min}$, the solution was centrifuged at $3500 \mathrm{rpm}$ for 1 hour, and the resulting supernatant was collected for TEM and AFM characterizations.

\section{Synthesis of series of $\mathrm{Pt} / \mathrm{Ti}_{3} \mathrm{C}_{2} \mathrm{~T}_{\mathrm{x}}$}

For a typical synthesis, $50 \mathrm{mg}$ of as-synthesized $\mathrm{Ti}_{3} \mathrm{C}_{2} \mathrm{~T}_{\mathrm{x}}$ MXene powder was immersed by $25 \mu \mathrm{L}$ of $\mathrm{Pt}\left(\mathrm{NH}_{3}\right)_{4}\left(\mathrm{NO}_{3}\right)_{2}$ aqueous solution $(0.02 \mathrm{~g} \mathrm{Pt} / \mathrm{mL})$. The mixture was vacuum dried and ground to ensure the homogeneity, labeled as $1 \mathrm{wt} . \% \mathrm{Pt} / \mathrm{Ti}_{3} \mathrm{C}_{2} \mathrm{~T}_{\mathrm{x}}$. The powder was then transferred into a tube furnace and reduced at different temperatures for at least $30 \mathrm{~min}$ under $3 \% \mathrm{H}_{2} / \mathrm{Ar}$ flow with a ramping rate of $5{ }^{\circ} \mathrm{C} / \mathrm{min}$ to obtained $\mathrm{Pt} / \mathrm{Ti}_{3} \mathrm{C}_{2} \mathrm{~T}_{\mathrm{x}}-n$ ( $n$ indicates the applied reduction temperature).

\section{Characterizations}

The mass loading of Pt was determined by using a Thermo Fisher Scientific X Series 2 inductively coupled plasma mass spectroscopy (ICP-MS). All the Pt-containing samples were digested in the boiling aqua regia solution, and the clear top layers were used for further analysis. X-ray diffraction (XRD) patterns were recorded at room temperature by a 
Bruker diffractometer with $\mathrm{Cu} \mathrm{K} \mathrm{K}_{\alpha}$ radiation source $(\lambda=1.5406 \AA)$. Transmission electron microscopy (TEM) images were recorded using a TECNAI G2 F20 electron microscope operated at $200 \mathrm{kV}$. High-resolution, high-angle annular dark field (HAADF) scanning transmission electron microscopy (STEM) imaging was acquired on a Titan Themis 300 probe corrected TEM with a Super-X EDX detector in the Sensitive Instrument Facility of Ames Lab. Extended X-ray absorption fine structure (EXAFS) measurement were performed in Argonne National Lab.

\section{Electrochemical Measurements}

All the electrochemical measurements were carried out in a three-electrode system using an electrochemical station (VSP-300, Bio-Logic Science Instruments). Typically, $10 \mathrm{mg}$ of catalysts were dispersed in $100 \mu \mathrm{L}$ of the mixture solution (water: isopropanol: Nafion solution $(5 \mathrm{wt} \%)=45: 45: 10)$ by sonication for $30 \mathrm{~min}$ to obtain a homogeneous ink. 20 $\mu \mathrm{L}$ of the above catalyst ink was then transferred onto $1 \mathrm{~cm}^{2}$ area on a carbon fiber electrode (Toray Paper 030) and dried at room temperature in air. We selected carbon fiber electrode instead of rotating disk electrode (RDE) because a high mass loading of $1 \% \mathrm{Pt} / \mathrm{Ti}_{3} \mathrm{C}_{2} \mathrm{~T}_{\mathrm{x}}$ catalyst (1-2mg) is required to achieve a reasonable Pt loading (10-20 $\mu \mathrm{g})$. Due to the small diameter of most commercial $\mathrm{RDE}$, the applied catalyst layer will be too thick to keep stay on the electrode and mass transfer is another problem. HER was conducted in a homemade $\mathrm{H}$-cell with two counterparts isolated by a Nafion-115 film, utilizing carbon fiber electrode with loaded catalysts as a working electrode, $\mathrm{Ag} / \mathrm{AgCl}$ (saturated $\mathrm{KCl}$ ) as a reference electrode, and a Pt gauze as the counter electrode. In a typical measurement, the Pt gauze counter electrode was placed in one counterpart while the working electrode and reference electrode were placed in the other counterpart containing $0.1 \mathrm{M} \mathrm{HClO}_{4}$ as the electrolyte saturated with $\mathrm{H}_{2}$. All the water used in electrochemistry study is the Millipore water $(18.2 \mathrm{M} \Omega \mathrm{cm})$.

\section{$\mathrm{H}_{2}$ chemisorption}

$\mathrm{H}_{2}$ chemisorption was performed in a Micromeritics ASAP 2020 unit. About $200 \mathrm{mg}$ of fresh $\mathrm{Pt} / \mathrm{Ti}_{3} \mathrm{C}_{2} \mathrm{~T}_{\mathrm{x}}$ catalysts were loaded in the sample tube, then the catalysts were reduced at different temperatures $\left(400^{\circ} \mathrm{C}, 550^{\circ} \mathrm{C}\right.$, and $\left.700^{\circ} \mathrm{C}\right)$ for 1 hour by $10 \% \mathrm{H}_{2} / \mathrm{Ar}(50 \mathrm{ml} / \mathrm{min})$ with a ramping rate of $5{ }^{\circ} \mathrm{C} / \mathrm{min}$. Then, the gas flow was switched to pure $\operatorname{Ar}(50 \mathrm{ml} / \mathrm{min})$, 
and the temperature was decreased and kept at $350^{\circ} \mathrm{C}$ for flushing out the adsorbed $\mathrm{H}_{2}$. Next, the temperature was decreased to the test temperature $\left(-60{ }^{\circ} \mathrm{C}\right)$ in $\operatorname{Ar}(50 \mathrm{ml} / \mathrm{min})$ with a stable baseline. Finally. $10 \% \mathrm{H}_{2} / \mathrm{Ar}$ was pulsed to the catalysts until no more $\mathrm{H}_{2}$ absorbed. The Pt dispersion is determined by the total $\mathrm{H}_{2}$ absorbed.

\section{DFT calculations}

Spin-polarized density functional theory (DFT) calculations were performed using the Vienna $\mathrm{Ab}$ initio Simulation Package (VASP) with projector augmented wave pseudopotentials. ${ }^{[1]}$ The revised Perdew-Burke-Ernzerhof (RPBE) ${ }^{[2]}$ exchange-correlation functional within the generalized gradient approximation (GGA) is chosen in consideration of a balance between accuracy and computational cost. ${ }^{[3]}$ The plane wave energy cutoff was $520 \mathrm{eV}$ for bulks and $400 \mathrm{eV}$ for surfaces. All the extended surfaces were modeled by periodic five-layer slabs separated by $30 \AA$ vacuum space along the norm of the surface, with $2 \times 2$ supercell for (111) and (100) surfaces and $2 \times 4$ supercell for (110) surfaces. The Brillouin zone was sampled on a $6 \times 6 \times 1$ Monkhorst-Pack k-point grid ${ }^{[4]}$ for $(111)$ and (100) surfaces and $6 \times 3 \times 1$ for (110) surfaces. The Pt-terminated surfaces were used for modeling $\mathrm{Pt}_{3} \operatorname{Ti}(110)$ and $\mathrm{Pt}_{3} \mathrm{Ti}(100)$ because of their lower surface energies than those of Ti-termination. The top three layers of the slab and adsorbates were fully relaxed until the maximum forces were converged to $0.05 \mathrm{eV} / \AA$. The computational hydrogen electrode is used for relating the free energy of the $\left(\mathrm{H}^{+}+\mathrm{e}^{-}\right)$pair at 0 vs. RHE to that of the gas phase $\mathrm{H}_{2}{ }^{[5]}$ Zero-point energy and entropic contributions to the free energies were taken from ref. ${ }^{[5]}$

The formation energy of bulk Pt3Ti is calculated according to equation (1):

$\mathrm{E}=\left[\mathrm{E}\left(\mathrm{Pt}_{3} \mathrm{Ti}\right)-3 * \mathrm{E}(\mathrm{Pt})-\mathrm{E}(\mathrm{Ti})\right] / 4$.

where $\mathrm{E}\left(\mathrm{Pt}_{3} \mathrm{Ti}\right)$ is the DFT calculated bulk energy of $\mathrm{Pt}_{3} \mathrm{Ti}, \mathrm{E}(\mathrm{Pt})$ is the DFT calculated bulk energy of Pt and E(Ti) is the DFT calculated bulk energy of Ti. Here we choose cubic structure for $\mathrm{Pt}_{3} \mathrm{Ti}, \mathrm{Pt}$ and $\mathrm{Ti}$. 

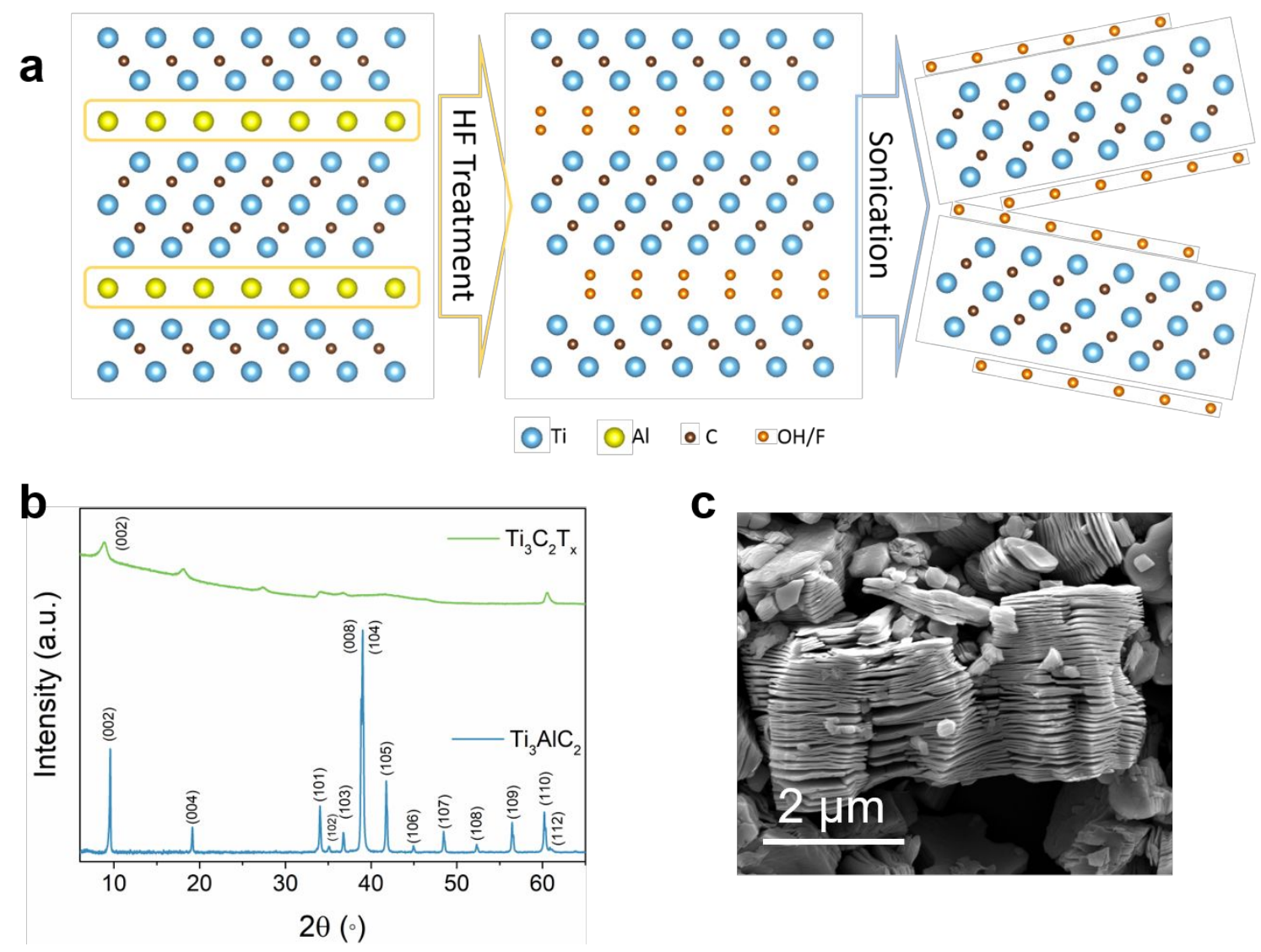

Figure S1. a) schematic illustration of the synthesis of $\mathrm{Ti}_{3} \mathrm{C}_{2} \mathrm{~T}_{\mathrm{x}}$ MXene. b) XRD patterns of $\mathrm{Ti}_{3} \mathrm{AlC}_{2} \mathrm{MAX}$ and $\mathrm{Ti}_{3} \mathrm{C}_{2} \mathrm{~T}_{\mathrm{x}}$ MXene. c) SEM of $\mathrm{Ti}_{3} \mathrm{C}_{2} \mathrm{~T}_{\mathrm{x}}$ MXene. 

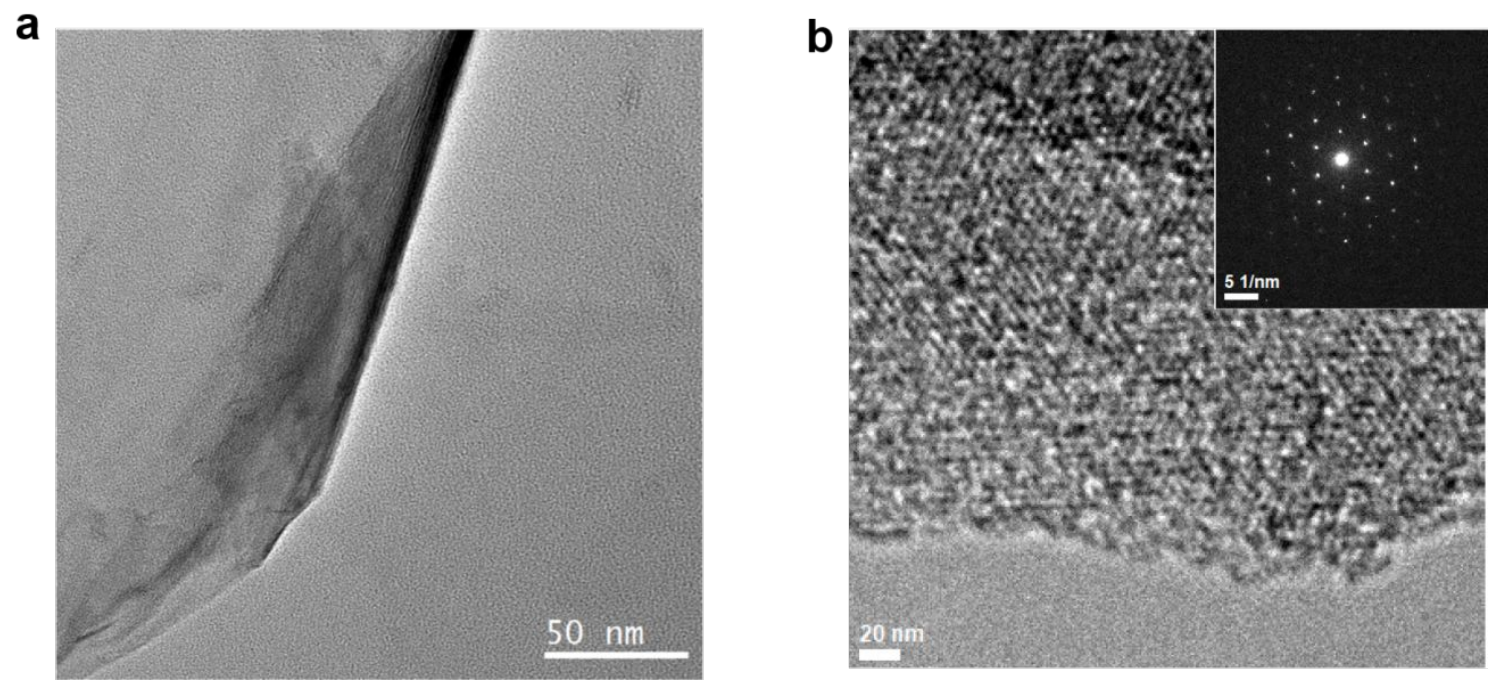

Figure S2. a) and b) High-resolution TEM image of $\mathrm{Ti}_{3} \mathrm{C}_{2} \mathrm{~T}_{\mathrm{x}} \mathrm{MXene}$. Inset of $\mathrm{b}$ ) is selected area electron diffraction (SAED).
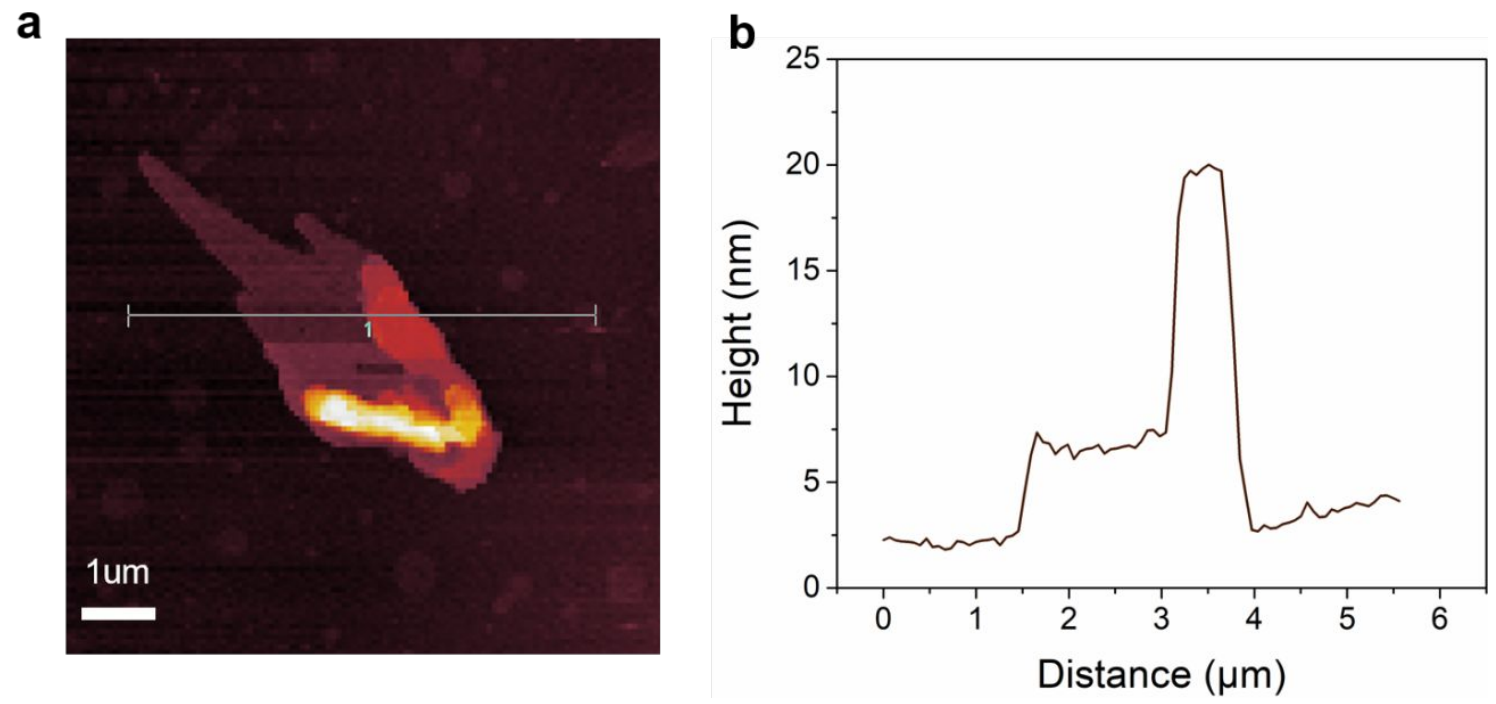

Figure S3. a) The AFM image of exfoliated MXene and b) the corresponding height measurement. 

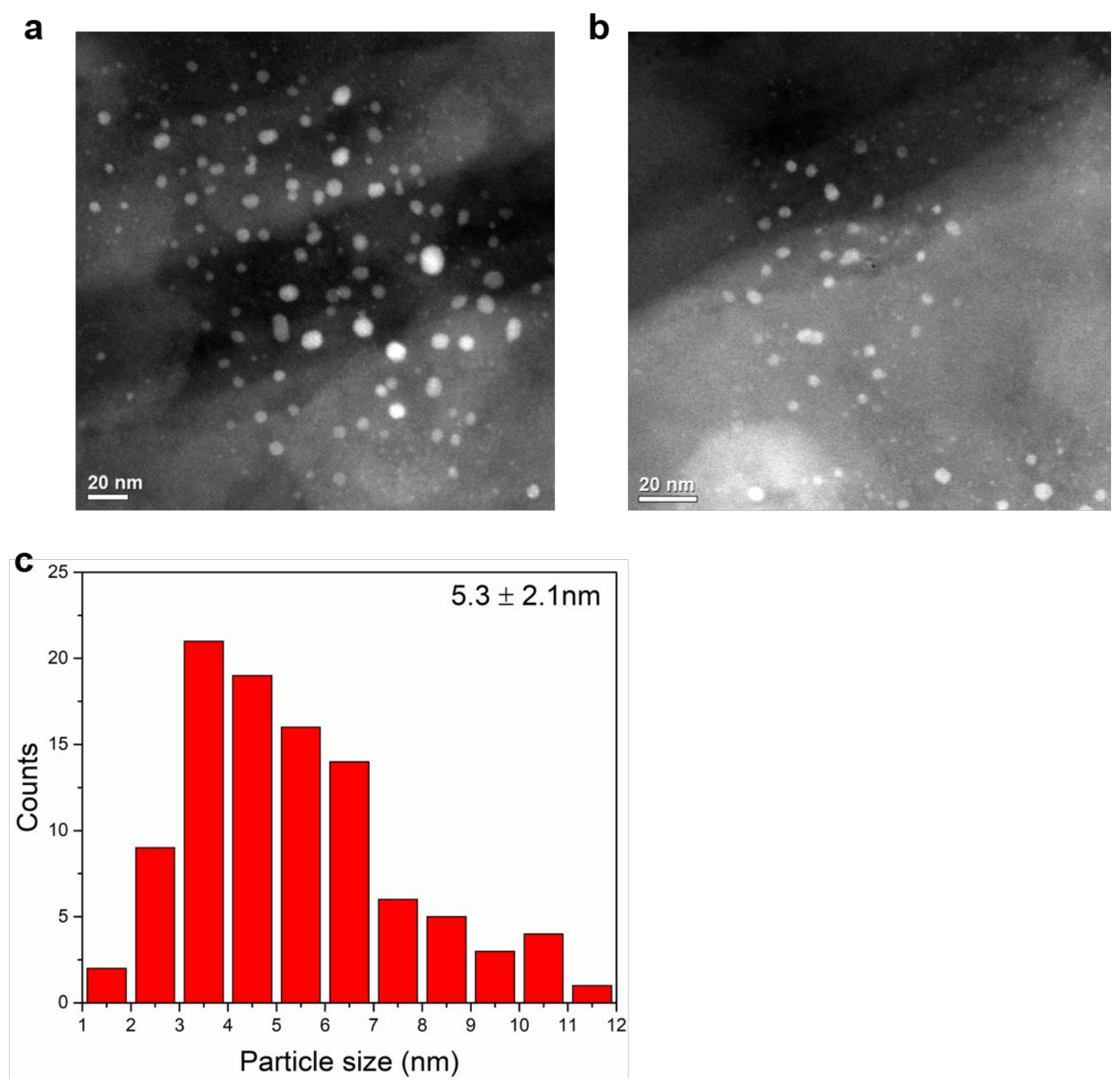

Figure S4. Particle size distribution of $\mathrm{Pt} / \mathrm{Ti}_{3} \mathrm{C}_{2} \mathrm{~T}_{\mathrm{x}}$ catalysts reduced at $400^{\circ} \mathrm{C}$. The average particle size is $5.3 \pm 2.1 \mathrm{~nm}$. 
a
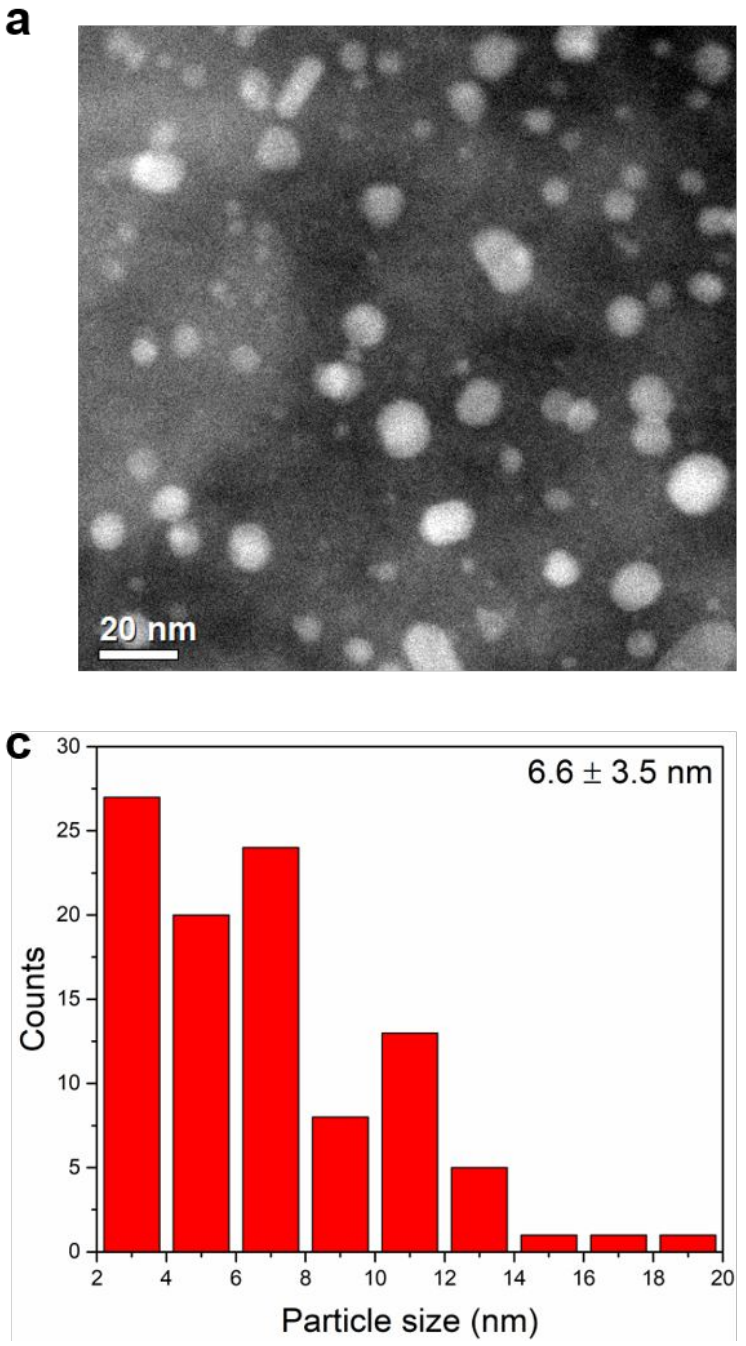

b

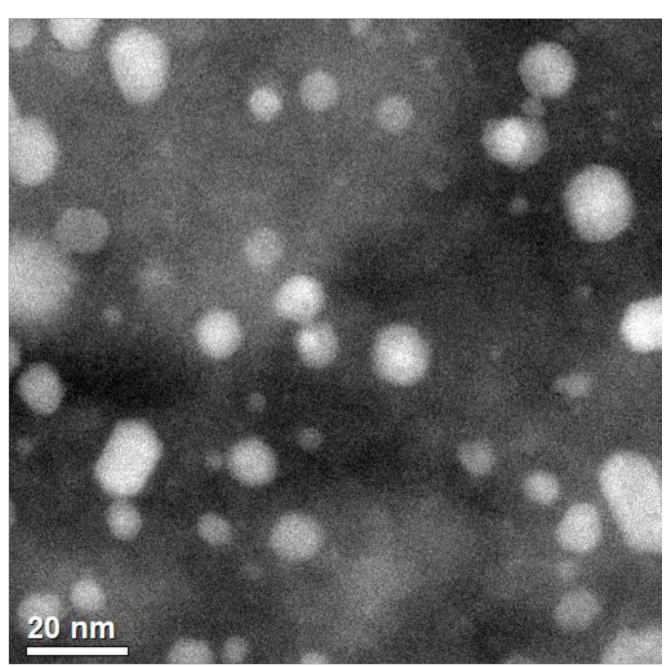

Figure S5. Particle size distribution of $\mathrm{Pt} / \mathrm{Ti}_{3} \mathrm{C}_{2} \mathrm{~T}_{\mathrm{x}}$ catalysts reduced at $550^{\circ} \mathrm{C}$. The average particle size is $6.6 \pm 3.5 \mathrm{~nm}$. 

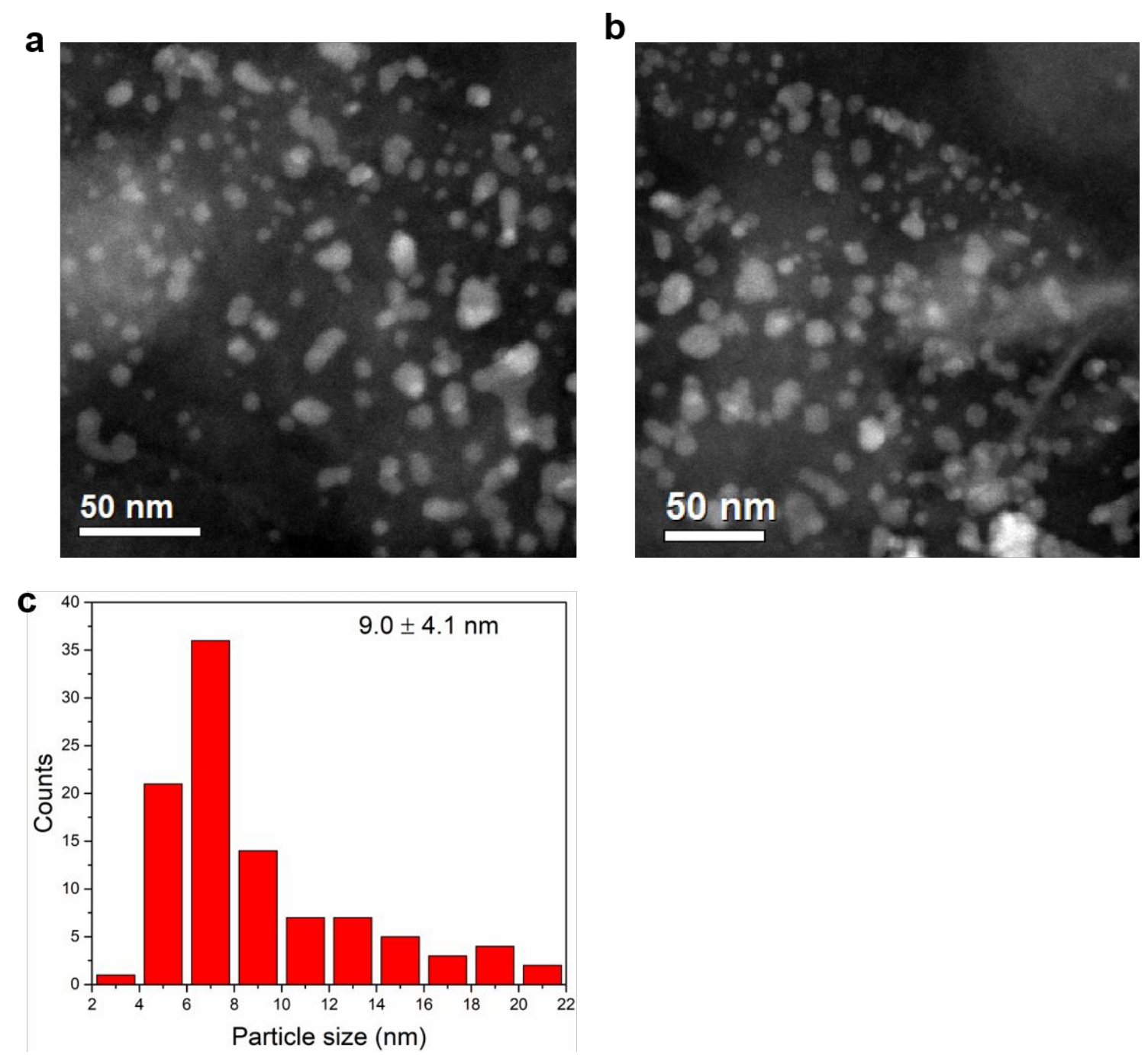

Figure S6. Particle size distribution of $\mathrm{Pt} / \mathrm{Ti}_{3} \mathrm{C}_{2} \mathrm{~T}_{\mathrm{x}}$ catalysts reduced at $700^{\circ} \mathrm{C}$. The average particle size is $9.0 \pm 4.1 \mathrm{~nm}$. 

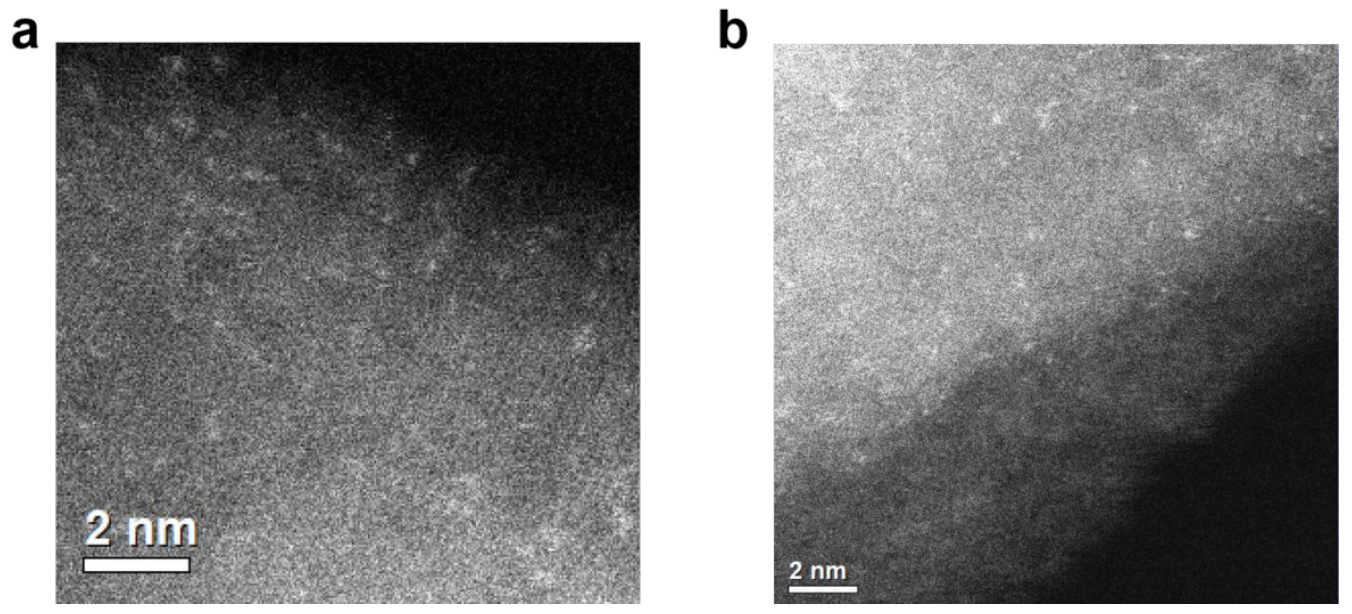

Figure S7 STEM image of $\mathrm{Pt} / \mathrm{Ti}_{3} \mathrm{C}_{2} \mathrm{~T}_{\mathrm{x}}$ catalysts reduced at $200^{\circ} \mathrm{C}$ showing single $\mathrm{Pt}$ atoms.
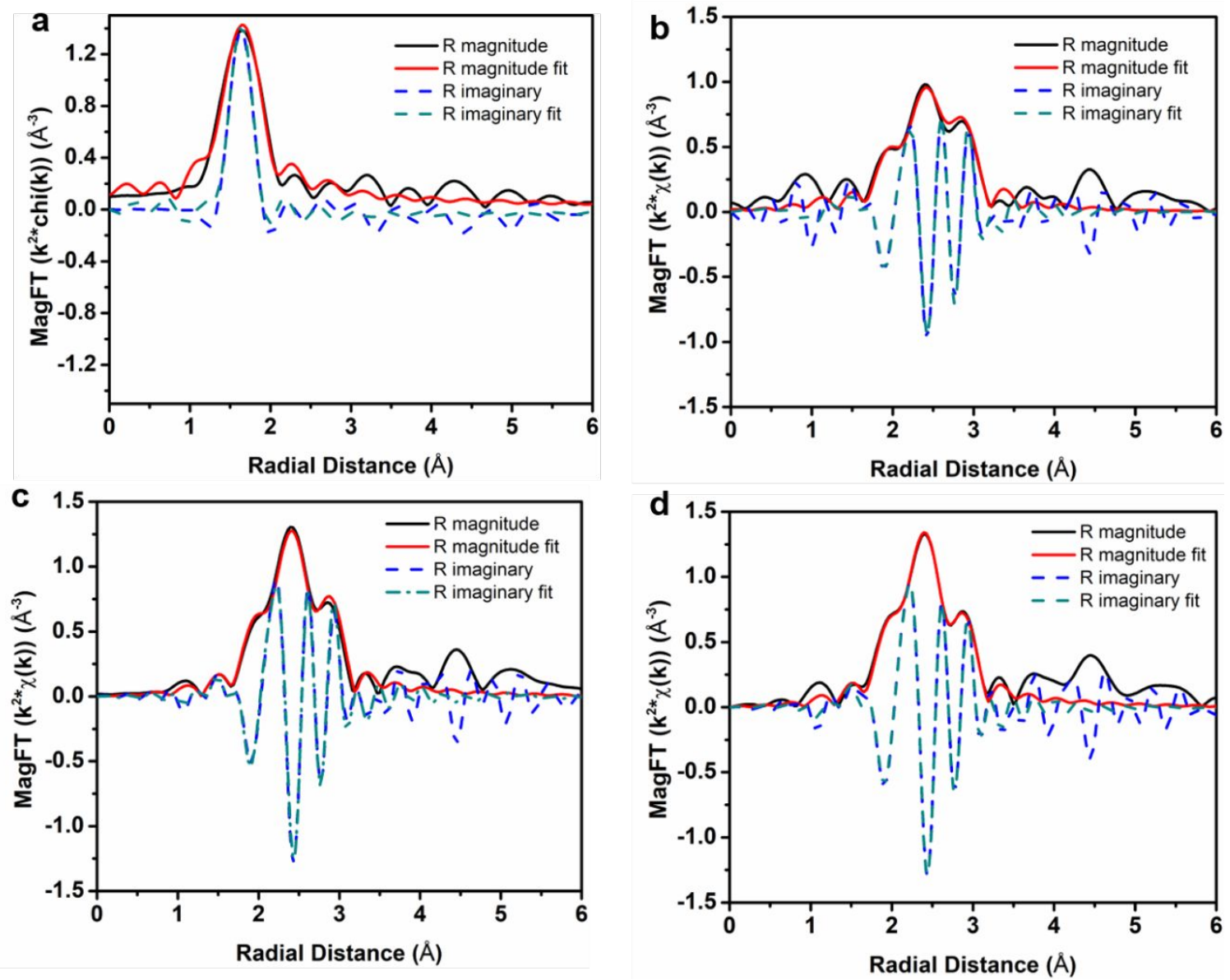

Figure S8. The magnitude (solid) and imaginary (dash) part of the Fourier transform of the $k^{2}$ weighted EXAFS and corresponding first shell fit for (a) $\mathrm{Pt} / \mathrm{Ti}_{3} \mathrm{C}_{2} \mathrm{~T}_{\mathrm{x}}-200$, (b) $\mathrm{Pt} / \mathrm{Ti}_{3} \mathrm{C}_{2} \mathrm{~T}_{\mathrm{x}}-400$, (c) $\mathrm{Pt} / \mathrm{Ti}_{3} \mathrm{C}_{2} \mathrm{~T}_{\mathrm{x}}-550$, and (d) $\mathrm{Pt} / \mathrm{Ti}_{3} \mathrm{C}_{2} \mathrm{~T}_{\mathrm{x}}-700$. 
a

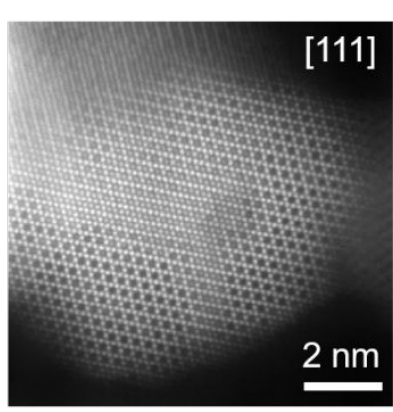

d

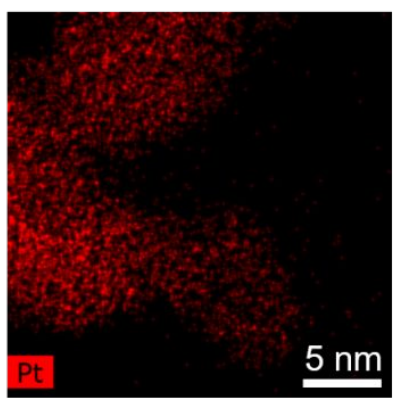

b

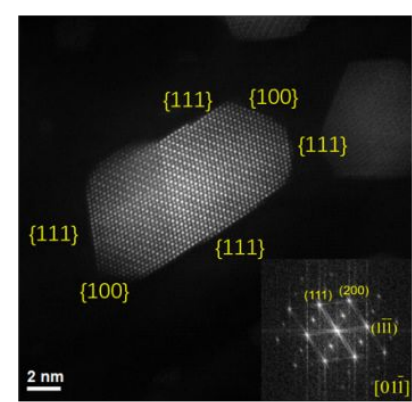

e

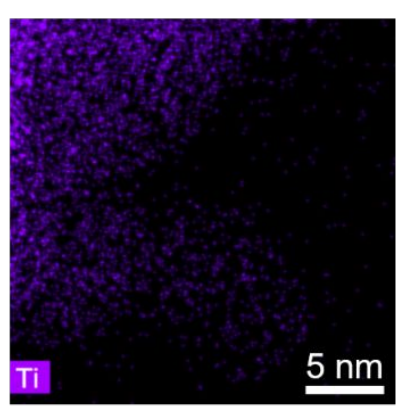

C

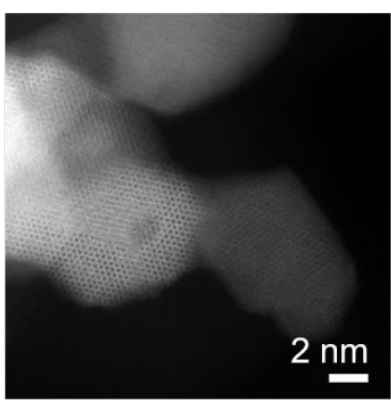

f

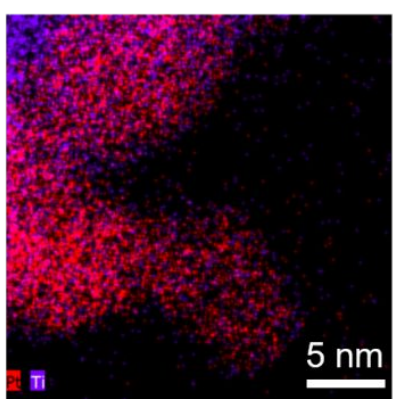

Figure S9. a-c) HAADF image of $\mathrm{Pt} / \mathrm{Ti}_{3} \mathrm{C}_{2} \mathrm{~T}_{\mathrm{x}}-700$. d-f) EDS elemental mapping of $\mathrm{Pt}$, Ti, and $\mathrm{Pt}+\mathrm{Ti}$, respectively.

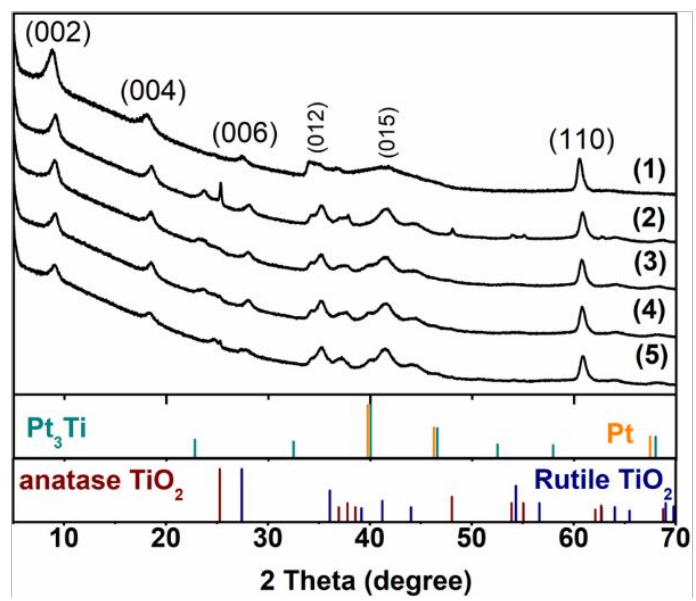

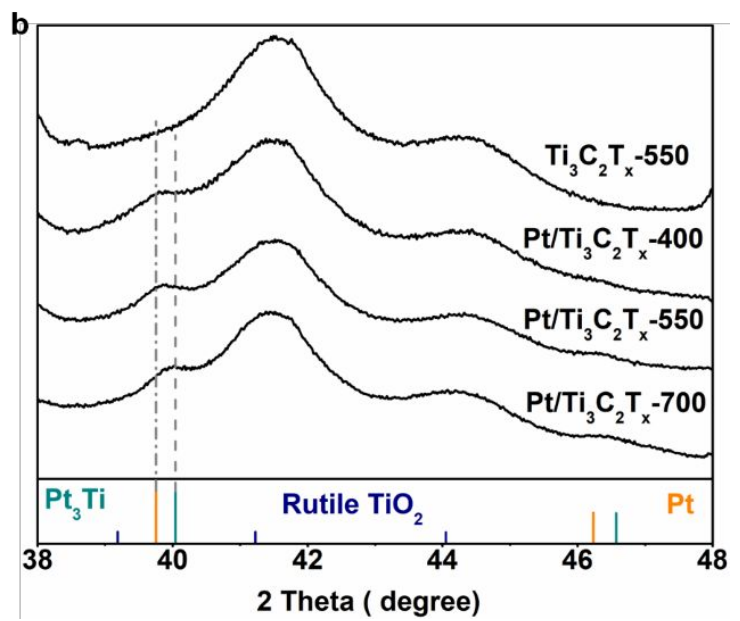

Figure $\mathrm{S10}$ a) XRDs of (1) $\mathrm{Ti}_{3} \mathrm{C}_{2} \mathrm{~T}_{\mathrm{x}}$ MXene, (2) $\mathrm{Ti}_{3} \mathrm{C}_{2} \mathrm{~T}_{\mathrm{x}}$ MXene reduced at $550^{\circ} \mathrm{C}$, (3) $\mathrm{Pt} / \mathrm{Ti}_{3} \mathrm{C}_{2} \mathrm{~T}_{\mathrm{x}}-400$, (4) $\mathrm{Pt} / \mathrm{Ti}_{3} \mathrm{C}_{2} \mathrm{~T}_{\mathrm{x}}-550$ and (5) $\mathrm{Pt} / \mathrm{Ti}_{3} \mathrm{C}_{2} \mathrm{~T}_{\mathrm{x}}-700$. b) XRDs in $38^{\circ}$ to $48^{\circ}$ region. 


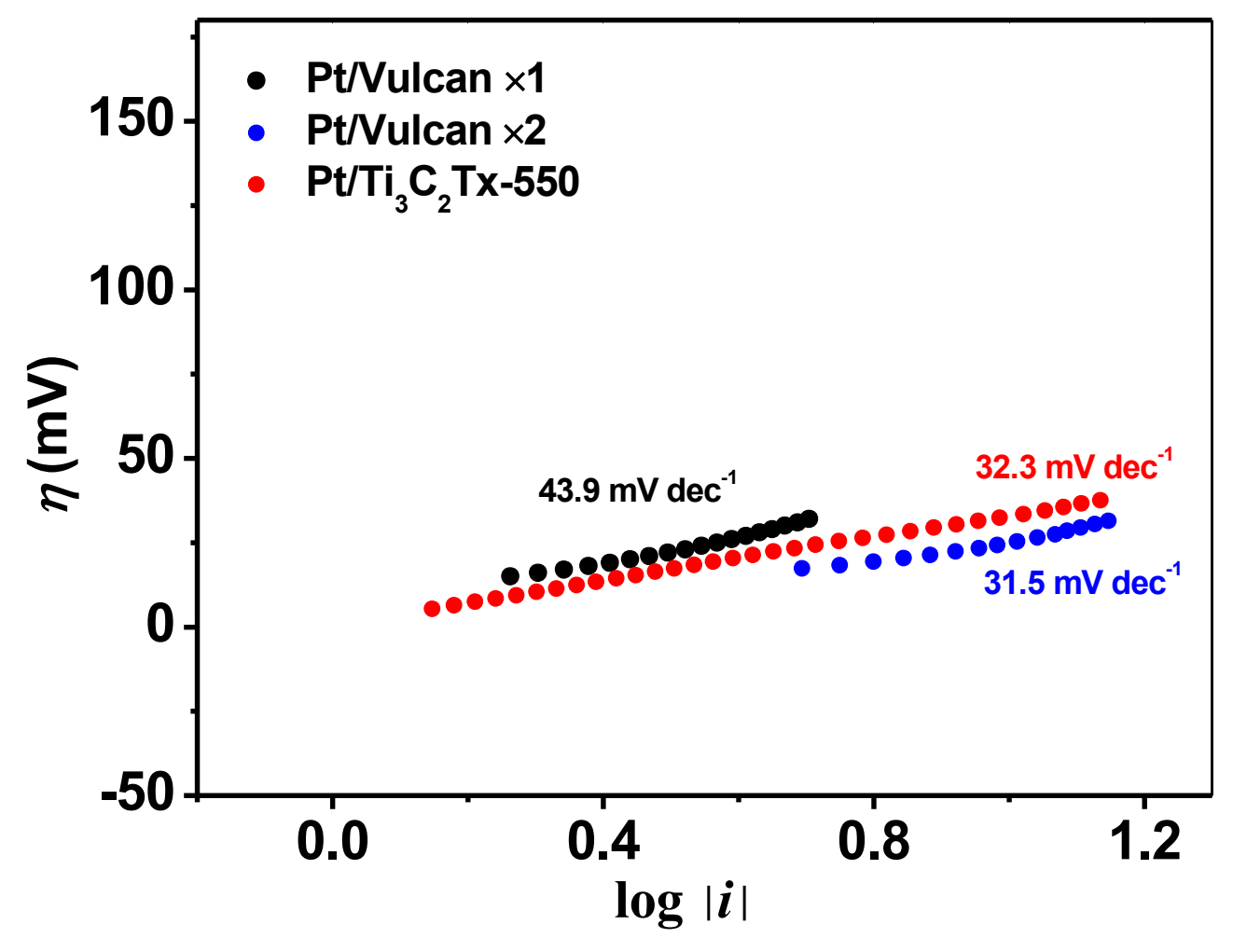

Figure S11 Tafel plot of Pt/Vulcan and $\mathrm{Pt} / \mathrm{Ti}_{3} \mathrm{C}_{2} \mathrm{~T}_{\mathrm{x}}-500$. Pt/Vulacan $\times 1$ and $\mathrm{Pt} / \mathrm{Ti}_{3} \mathrm{C}_{2} \mathrm{~T}_{\mathrm{x}}-500$ contain the same amount of $\mathrm{Pt}(21 \mu \mathrm{g})$. Catalyst loading was doubled for $\mathrm{Pt} / \mathrm{Vulacan} \times 2$, i.e., $\mathrm{Pt} /$ Vulacan $\times 2$ contains $42 \mu \mathrm{g} \mathrm{Pt}$. 

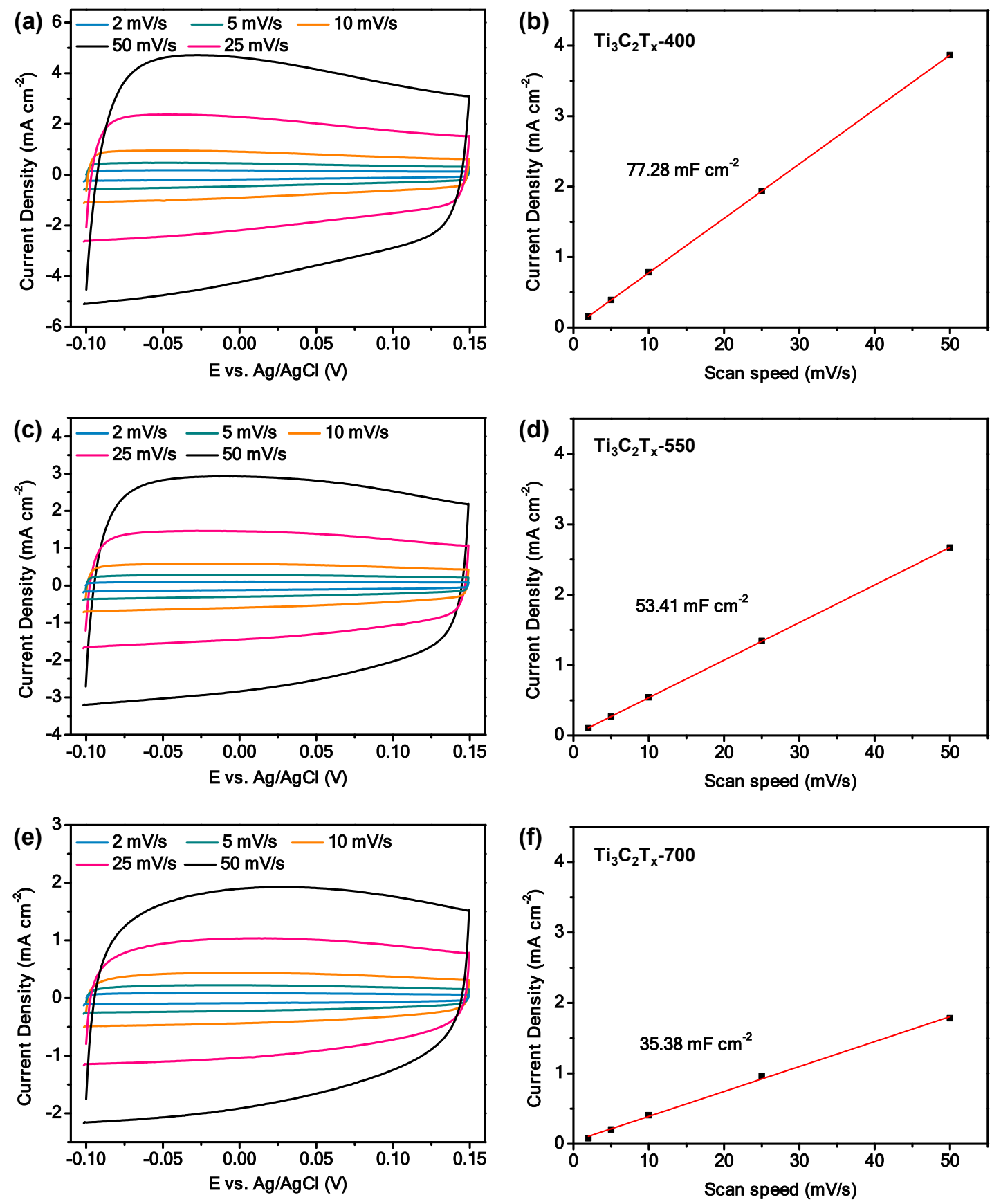

Figure S12. CV curves measured from $-0.10 \mathrm{~V}$ to $0.15 \mathrm{~V}$ vs $\mathrm{Ag} / \mathrm{AgCl}$ at different scan speed, and electrochemical double layer capacitance calculation of bare support $(a, b)$ $\mathrm{Ti}_{3} \mathrm{C}_{2} \mathrm{~T}_{\mathrm{x}}-400,(\mathrm{c}, \mathrm{d}) \mathrm{Ti}_{3} \mathrm{C}_{2} \mathrm{~T}_{\mathrm{x}}-550$, and (e, f) $\mathrm{Ti}_{3} \mathrm{C}_{2} \mathrm{~T}_{\mathrm{x}}-700$. The current density at $0.05 \mathrm{~V}$ vs. $\mathrm{Ag} / \mathrm{AgCl}$ was used for the calculation. 
(a)
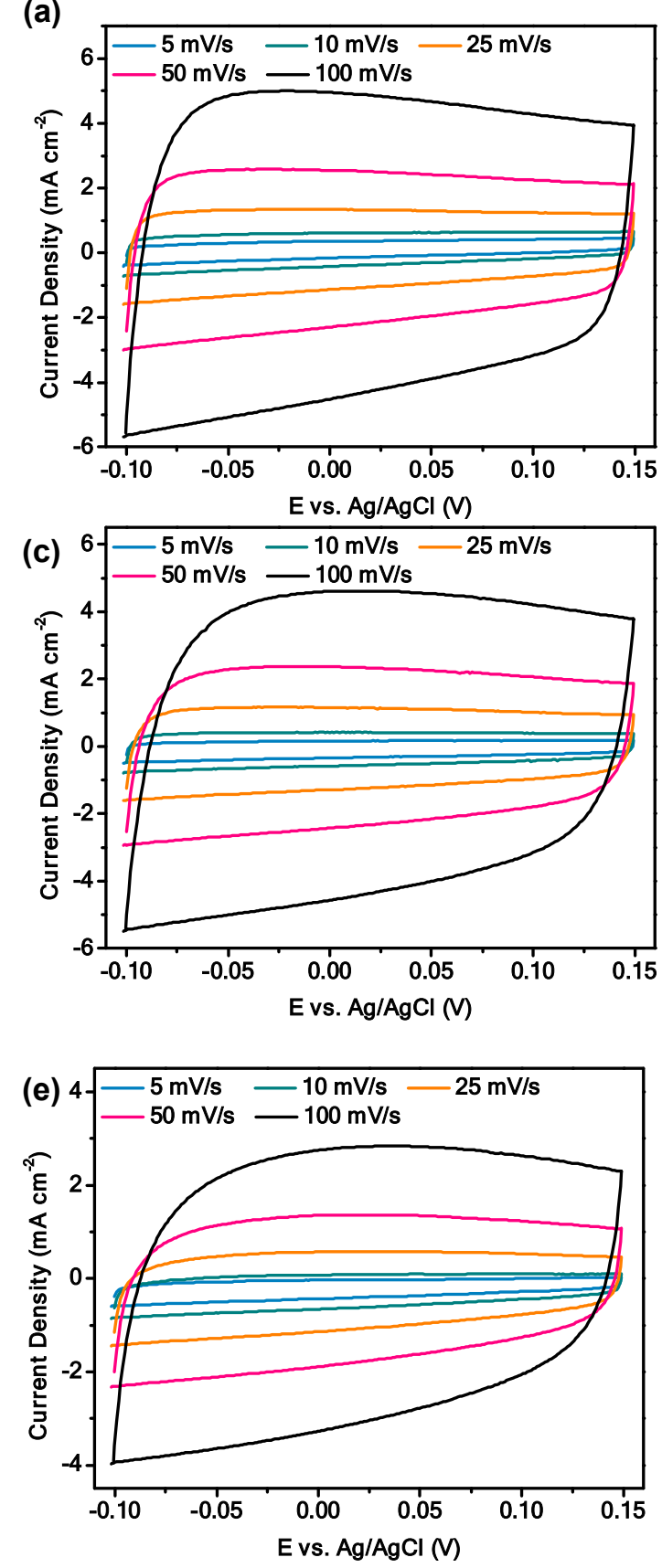
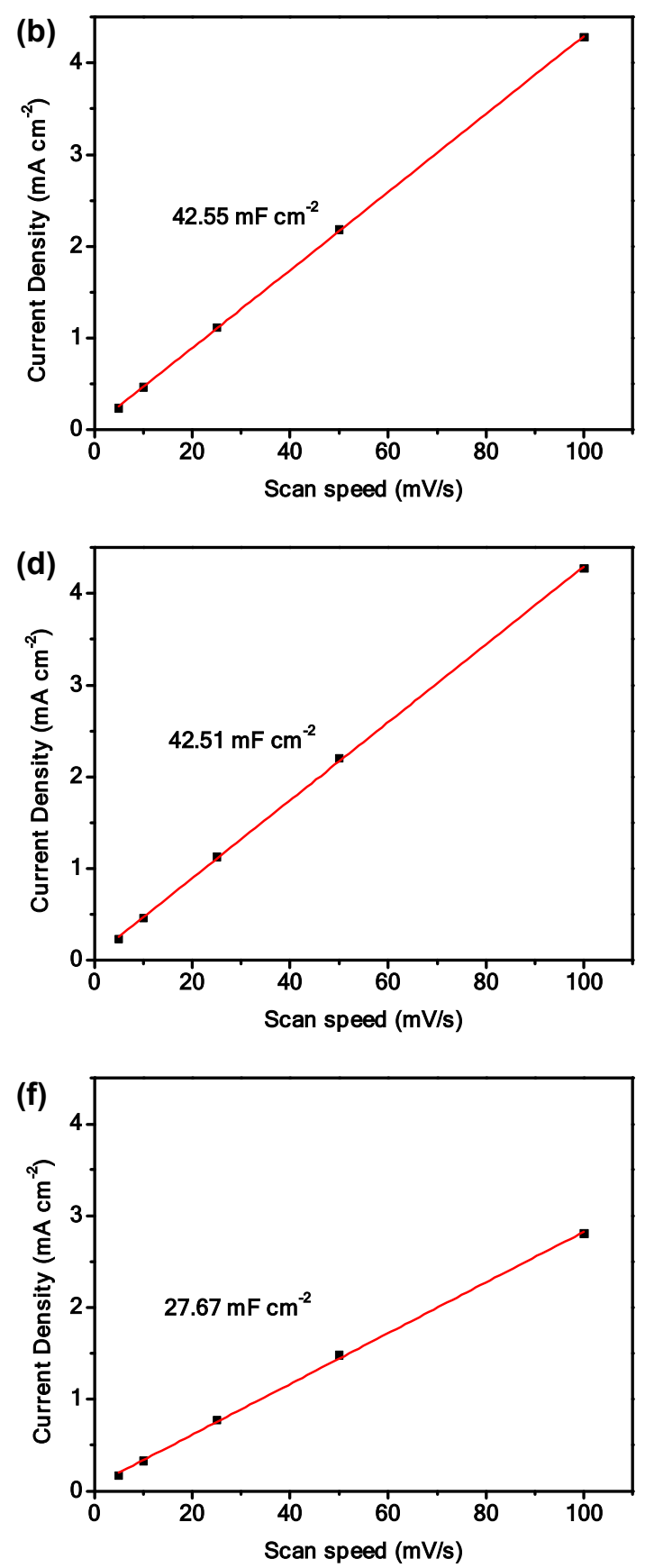

Figure S13. CV curves measured from $-0.10 \mathrm{~V}$ to $0.15 \mathrm{~V}$ vs $\mathrm{Ag} / \mathrm{AgCl}$ at different scan speed, and electrochemical double layer capacitance calculation of bare support $(\mathrm{a}, \mathrm{b})$ $\mathrm{Pt} / \mathrm{Ti}_{3} \mathrm{C}_{2} \mathrm{~T}_{\mathrm{x}}-400$, (c, d) $\mathrm{Pt} / \mathrm{Ti}_{3} \mathrm{C}_{2} \mathrm{~T}_{\mathrm{x}}-550$, and $(\mathrm{e}, \mathrm{f}) \mathrm{Pt} / \mathrm{Ti}_{3} \mathrm{C}_{2} \mathrm{~T}_{\mathrm{x}}-700$. The current density at $0.05 \mathrm{~V}$ vs. $\mathrm{Ag} / \mathrm{AgCl}$ was used for the calculation. 


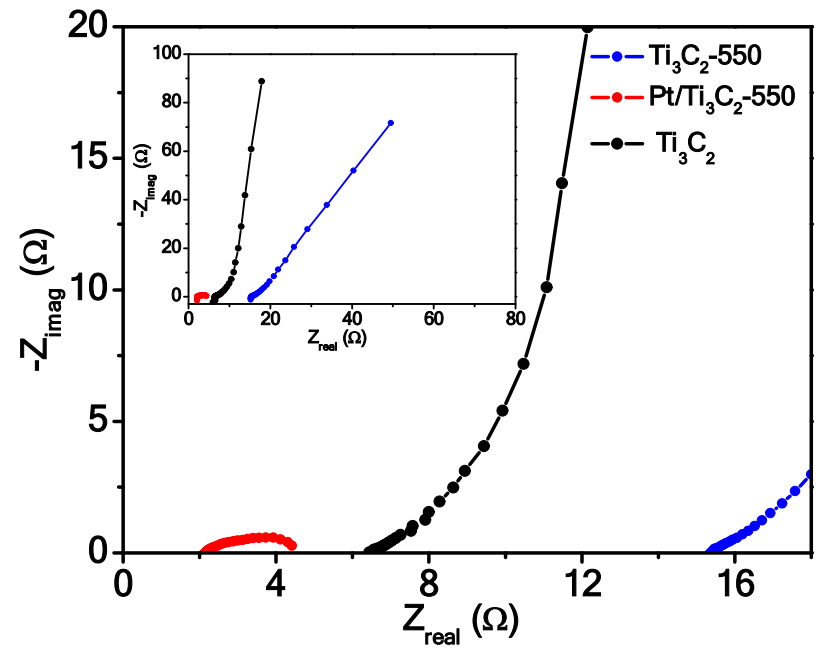

Figure S14. Nyquist plot of $\mathrm{Pt} / \mathrm{Ti}_{3} \mathrm{C}_{2} \mathrm{~T}_{\mathrm{x}}-550, \mathrm{Ti}_{3} \mathrm{C}_{2}$ and control samples $\mathrm{Ti}_{3} \mathrm{C}_{2}-550$ measured at $0 \mathrm{~V}$ vs. RHE.
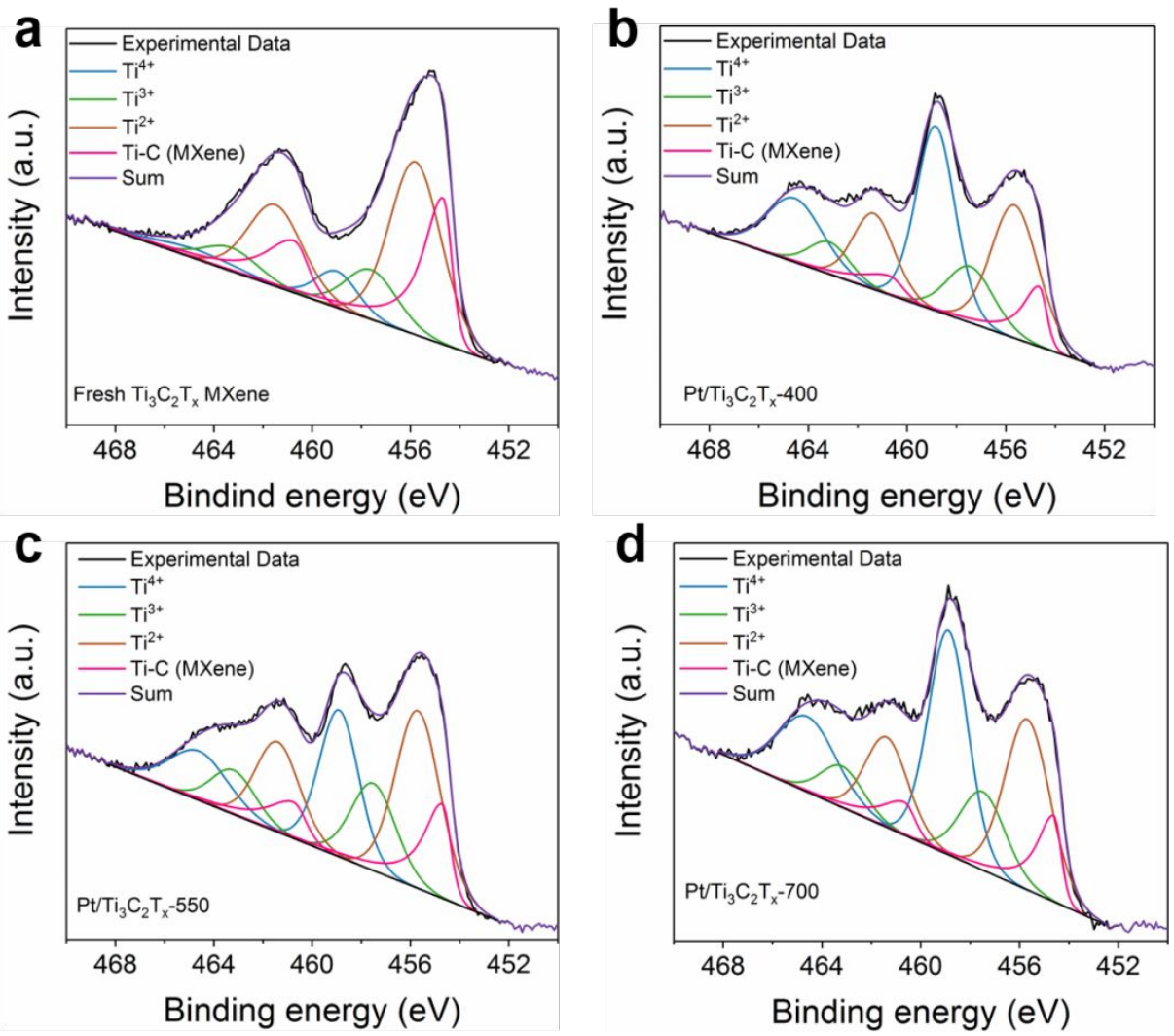

Figure S15 a) High resolution Ti $2 p$ XPS spectrum of $\mathrm{Ti}_{3} \mathrm{C}_{2} \mathrm{~T}_{\mathrm{x}}$, b) $\mathrm{Pt} / \mathrm{Ti}_{3} \mathrm{C}_{2} \mathrm{~T}_{\mathrm{x}}-400$, c) $\mathrm{Pt} / \mathrm{Ti}_{3} \mathrm{C}_{2} \mathrm{~T}_{\mathrm{x}}-550$ and d) $\mathrm{Pt} / \mathrm{Ti}_{3} \mathrm{C}_{2} \mathrm{~T}_{\mathrm{x}}-700$. 

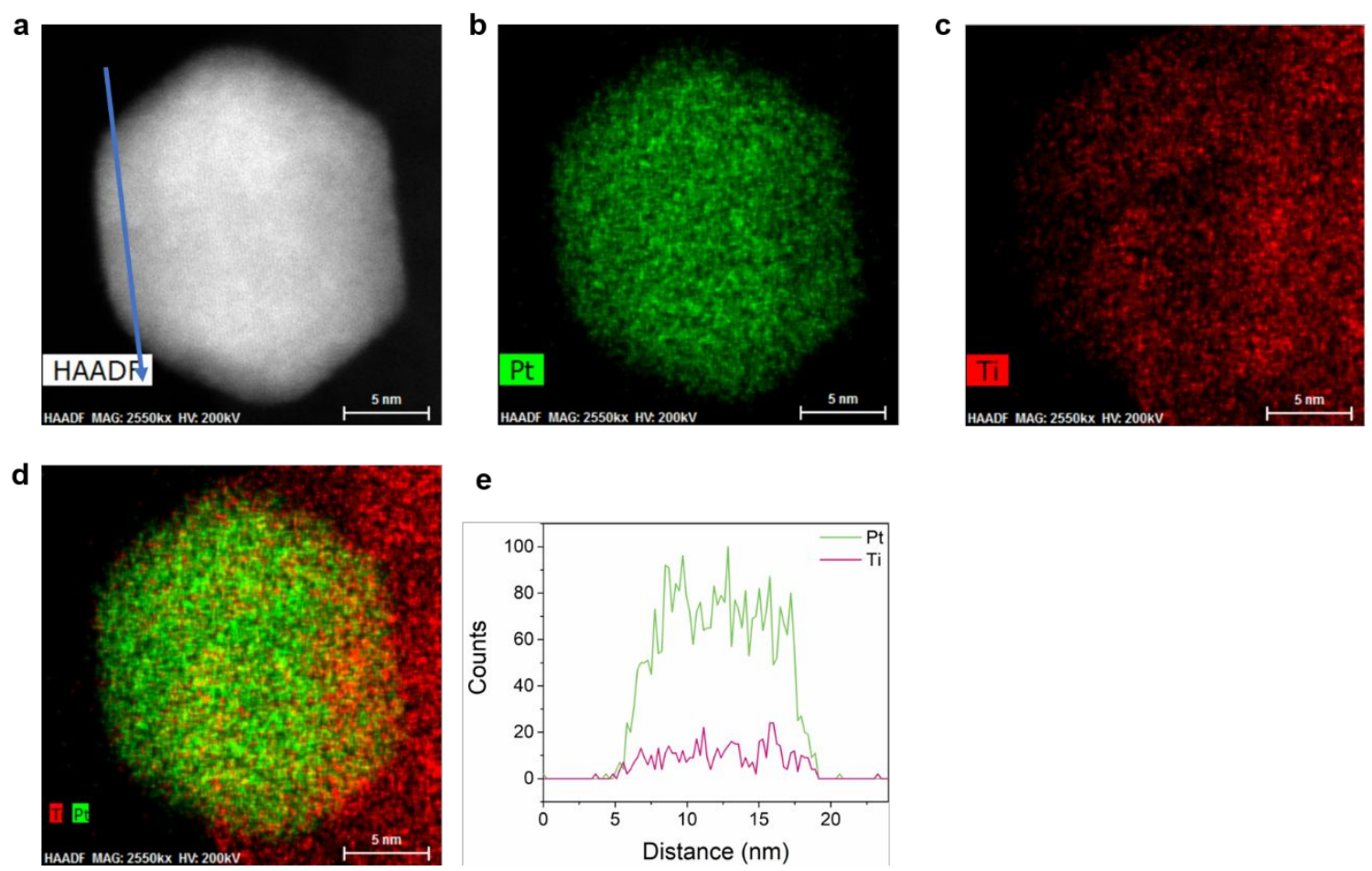

e

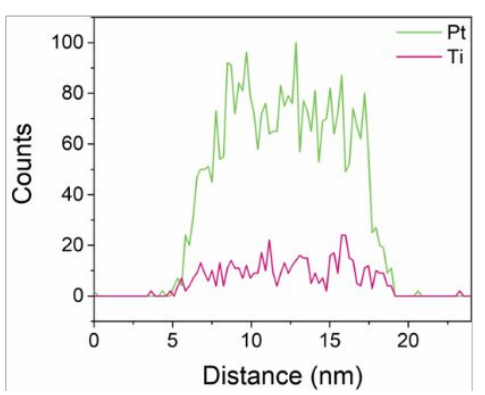

Figure S16. a) HAADF image of used $\mathrm{Pt} / \mathrm{Ti}_{3} \mathrm{C}_{2} \mathrm{~T}_{\mathrm{x}}$ HER catalysts. b-d) EDS elemental mappings of the used $\mathrm{Pt} / \mathrm{Ti}_{3} \mathrm{C}_{2} \mathrm{~T}_{\mathrm{x}}$ catalysts. e) EDS line scans for the nanoparticle in a).

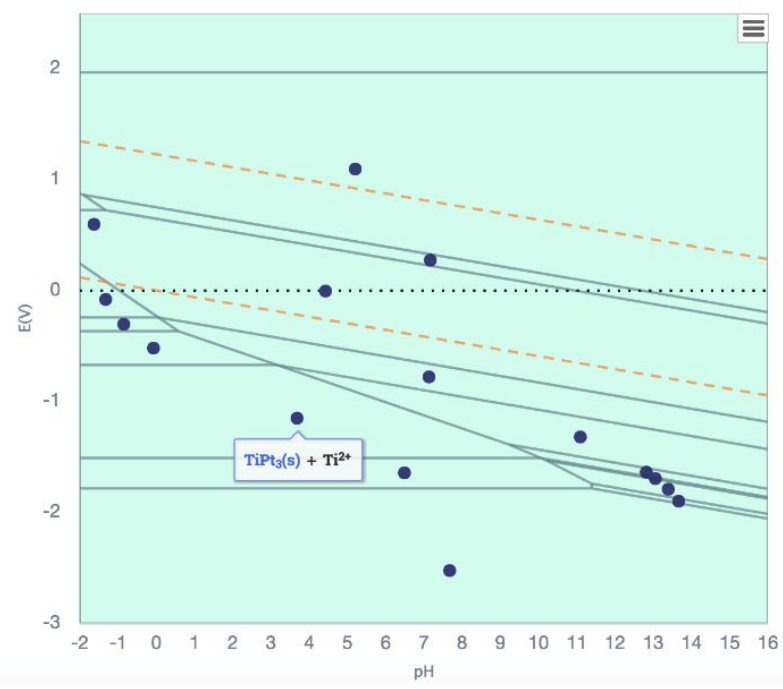

Figure S17 Pourbaix diagram of Ti+Pt system as calculated from materialsproject.org. 

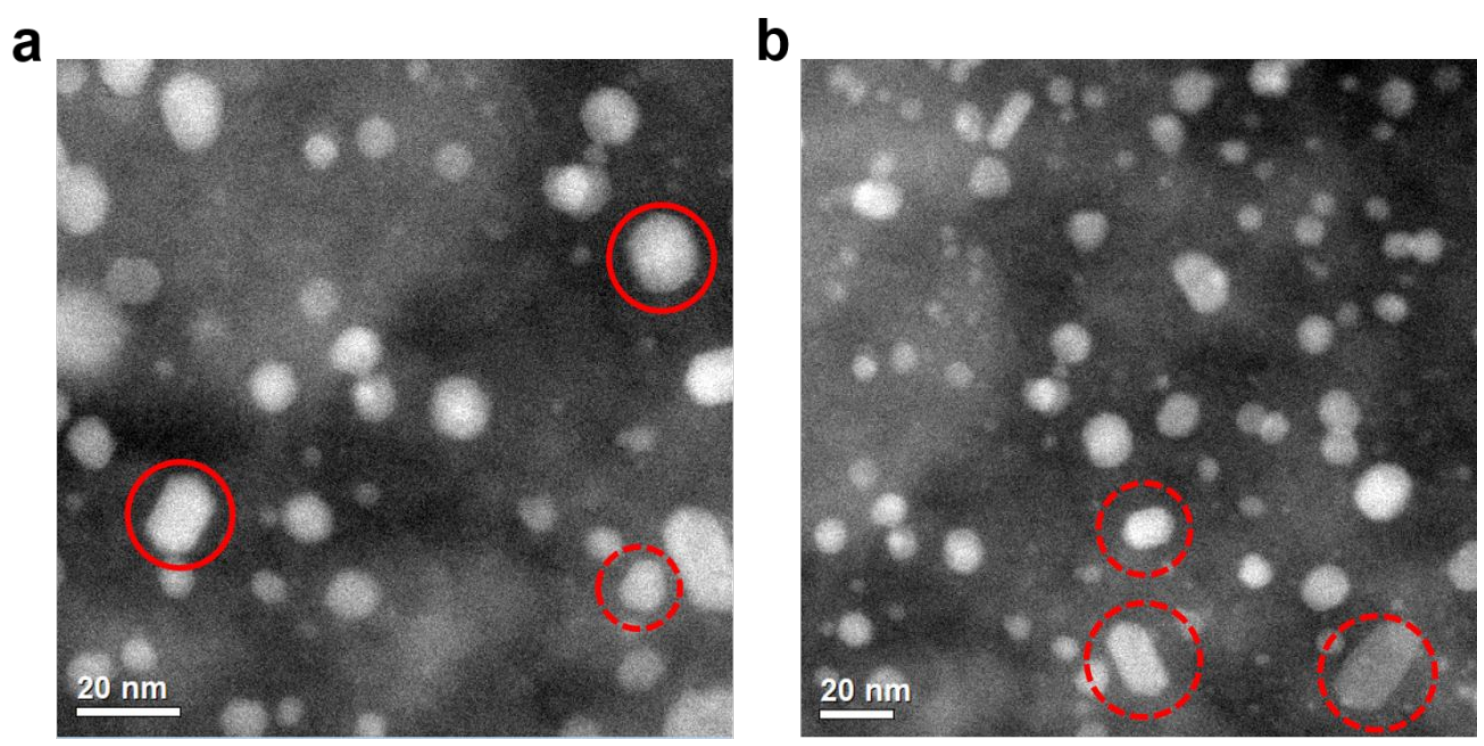

Figure S18 STEM images of $\mathrm{Pt} / \mathrm{Ti}_{3} \mathrm{C}_{2} \mathrm{~T}_{\mathrm{x}}$ reduced at $550{ }^{\circ} \mathrm{C}$ showing nanoparticles with cuboctahedral morphology. 
Table S1 Quantitative information of the XANES data and EXAFS fits

\begin{tabular}{|c|c|c|c|c|c|c|c|}
\hline Samples & $\begin{array}{l}\text { Edge Energy } \\
(\mathrm{KeV})\end{array}$ & $\begin{array}{l}\text { Scattering } \\
\text { Pair }\end{array}$ & $S_{0}^{2[\mathrm{a}]}$ & $\mathrm{CN}^{[\mathrm{b}]}$ & $r(\AA)^{[\mathrm{b}]}$ & $\Delta E_{0}(\mathrm{eV})^{[\mathrm{b}]}$ & $\sigma^{2}\left(\AA^{2}\right)^{[b]}$ \\
\hline Pt Foil & 11.5640 & $\mathrm{Pt}-\mathrm{Pt}$ & 0.77 & 12 & 2.76 & 7.7 & 0.004 \\
\hline $\begin{array}{l}2 \% \mathrm{Pt} / \mathrm{SiO}_{2} \\
550^{\circ} \mathrm{C}\end{array}$ & 11.5640 & $\mathrm{Pt}-\mathrm{Pt}$ & $0.77 *$ & 8.6 & 2.74 & 7.1 & 0.006 \\
\hline $\begin{array}{l}\mathrm{Pt} / \mathrm{Ti}_{3} \mathrm{C}_{2} \mathrm{~T}_{\mathrm{x}} \\
200{ }^{\circ} \mathrm{C}\end{array}$ & 11.5653 & $\mathrm{Pt}-\mathrm{N}(\mathrm{O})$ & $0.77 *$ & 4.1 & 2.06 & 7.7 & 0.003 \\
\hline $\begin{array}{l}\mathrm{Pt} / \mathrm{Ti}_{3} \mathrm{C}_{2} \mathrm{~T}_{\mathrm{x}} \\
400{ }^{\circ} \mathrm{C}\end{array}$ & 11.5640 & $\begin{array}{l}\text { Pt-Pt } \\
\text { Pt-Ti }\end{array}$ & $0.77 *$ & $\begin{array}{l}8.5 \\
0.3\end{array}$ & $\begin{array}{l}2.75 \\
2.74\end{array}$ & 4.6 & $\begin{array}{l}0.006 \\
0.015\end{array}$ \\
\hline $\begin{array}{l}\mathrm{Pt} / \mathrm{Ti}_{3} \mathrm{C}_{2} \mathrm{~T}_{\mathrm{x}} \\
550{ }^{\circ} \mathrm{C}\end{array}$ & 11.5646 & $\begin{array}{l}\text { Pt-Pt } \\
\text { Pt-Ti }\end{array}$ & $0.77 *$ & $\begin{array}{l}6.6 \\
3.4\end{array}$ & $\begin{array}{l}2.75 \\
2.75\end{array}$ & 6.8 & $\begin{array}{l}0.006 \\
0.015\end{array}$ \\
\hline $\begin{array}{l}\mathrm{Pt} / \mathrm{Ti}_{3} \mathrm{C}_{2} \mathrm{~T}_{\mathrm{x}} \\
700{ }^{\circ} \mathrm{C}\end{array}$ & 11.5648 & $\begin{array}{l}\mathrm{Pt}-\mathrm{Pt} \\
\mathrm{Pt}-\mathrm{Ti}\end{array}$ & $0.77 *$ & $\begin{array}{l}7.2 \\
4.1\end{array}$ & $\begin{array}{l}2.75 \\
2.74\end{array}$ & 5.9 & $\begin{array}{l}0.006 \\
0.015\end{array}$ \\
\hline
\end{tabular}

[a] The $S_{0}^{2}$ (reduction factor) is fixed at the value obtained by fitting a Pt foil reference.

[b] The errors of all the fitted parameters are very close. The average error in $\mathrm{CN}$ (coordination number) is 0.5 , in $r$ (bond length) is $0.003 \AA$, in $\Delta E_{0}$ (energy shift) is $0.5 \mathrm{eV}$ and in $\sigma^{2}$ (Debye-Waller factor) is $0.001 \AA^{2}$.

Table S2 Summary of HER activity catalyzed by different Pt-Ti/MXene catalysts.

\begin{tabular}{|c|c|c|c|c|}
\hline Samples & $\mathrm{Pt} w \mathrm{t} \%$ & Mass of Pt $(\mu g)$ & $\eta @ 10 \mathrm{~mA}(\mathrm{mV})$ & $\eta @ 40 \mathrm{~mA}(\mathrm{mV})$ \\
\hline Pt/Vulcan & 20.0 & 22.0 & 55.8 & 159.1 \\
\hline $\mathrm{Pt} / \mathrm{Ti}_{3} \mathrm{C}_{2} \mathrm{~T}_{\mathrm{x}}-200$ & 0.89 & 21.1 & 270.8 & 382.5 \\
\hline $\mathrm{Pt} / \mathrm{Ti}_{3} \mathrm{C}_{2} \mathrm{~T}_{\mathrm{x}}-550$ & 1.0 & 21.9 & 32.7 & 60.8 \\
\hline $\mathrm{Pt} / \mathrm{Ti}_{3} \mathrm{C}_{2} \mathrm{~T}_{\mathrm{x}}-700$ & 1.2 & 30.7 & 122.3 & 270.6 \\
\hline $\mathrm{Pt} / \mathrm{Ti}_{3} \mathrm{C}_{2} \mathrm{~T}_{\mathrm{x}}-400$ & 1.0 & 20.4 & 73.0 & 175.8 \\
\hline $\mathrm{Ti}_{3} \mathrm{C}_{2}$ & - & - & 576.8 & - \\
\hline
\end{tabular}


Table S3 Summary of HER mass activity and specific activity at $50 \mathrm{mV}$ and $70 \mathrm{mV}$ overpotential

\begin{tabular}{|c|c|c|c|c|c|c|c|c|}
\hline Samples & $\begin{array}{l}\text { Total Pt } \\
\text { mass (ug) }\end{array}$ & $\begin{array}{l}\text { Pt dispersion } \\
(\%) \text { measured } \\
\text { at }-60^{\circ} \mathrm{C}\end{array}$ & $\begin{array}{l}50 \mathrm{mV} \\
\text { current }(\mathrm{mA})\end{array}$ & $\begin{array}{l}50 \mathrm{mV} \\
\text { Mass } \\
\text { activity } \\
\text { (mA/ug) }\end{array}$ & $\begin{array}{l}50 \mathrm{mV} \\
\text { specific } \\
\text { acitvity } \\
(\mathrm{mA} / \mathrm{ug} \\
\text { surface } \mathrm{Pt}) \\
\end{array}$ & $\begin{array}{l}70 \mathrm{mV} \\
\text { current }(\mathrm{mA})\end{array}$ & $\begin{array}{l}70 \mathrm{mV} \\
\text { Mass } \\
\text { activity } \\
(\mathrm{mA} / \mathrm{ug})\end{array}$ & $\begin{array}{l}70 \mathrm{mV} \\
\text { specific } \\
\text { acitvity } \\
(\mathrm{mA} / \mathrm{ug} \\
\text { surface } \mathrm{Pt}) \\
\end{array}$ \\
\hline $\mathrm{Pt} / \mathrm{Ti}_{3} \mathrm{C}_{2} \mathrm{~T}_{\mathrm{x}}-550$ & 20.0 & 7.6 & 26.10 & 1.305 & 17.17 & 52.6 & 2.63 & 34.61 \\
\hline Pt/Vulcan & 22.0 & 22.2 & 8.73 & 0.397 & 1.79 & 12.97 & 0.59 & 2.66 \\
\hline $\mathrm{Pt} / \mathrm{Ti}_{3} \mathrm{C}_{2} \mathrm{~T}_{\mathrm{x}}-400$ & 20.4 & 10.6 & 5.36 & 0.263 & 2.48 & 9.46 & 0.46 & 4.37 \\
\hline $\mathrm{Pt} / \mathrm{Ti}_{3} \mathrm{C}_{2} \mathrm{~T}_{\mathrm{x}}-700$ & 30.7 & 3.2 & 1.21 & 0.039 & 1.23 & 3.78 & 0.12 & 3.85 \\
\hline
\end{tabular}


Table S4. Literature summary of HER activity in acidic condition

\begin{tabular}{|c|c|c|c|c|c|c|}
\hline Catalysts & $\begin{array}{c}\text { Overpotential@ } \\
10 \mathrm{~mA} \mathrm{~cm}{ }^{-2} \\
(\mathrm{mV})\end{array}$ & $\begin{array}{c}\text { Real } \\
\text { current } \\
\text { @ } 10 \mathrm{~mA} \\
\mathrm{~cm}^{-2} \\
(\mathrm{~mA})\end{array}$ & $\begin{array}{l}\text { Tafel slope } \\
\left.(\mathrm{mV} \mathrm{dec})^{-1}\right)\end{array}$ & $\begin{array}{c}\text { Catalyst } \\
\text { loading } \\
\left(\mathrm{mg} \mathrm{cm}^{-2}\right)\end{array}$ & $\begin{array}{c}\text { Mass } \\
\text { activity@ } \\
50 \mathrm{mV} \\
(\mathrm{mA} / \mu \mathrm{g})^{\mathrm{a}}\end{array}$ & Reference \\
\hline $\mathrm{Pt} / \mathrm{Ti}_{3} \mathrm{C}_{2}-550$ & 32.7 & 10 & 32.3 & $\begin{array}{c}20 \mu \mathrm{g} \mathrm{Pt} \\
\mathrm{cm}^{-2}\end{array}$ & 1.31 & This work \\
\hline$\overline{\mathrm{Pt} / \mathrm{DNA}}$ & 30 & 0.71 & 26 & $\begin{array}{c}15 \mu \mathrm{g} \mathrm{Pt} \\
\mathrm{cm}^{-2}\end{array}$ & 1.26 & {$[6]$} \\
\hline $\mathrm{Pt} / \mathrm{MoS}_{2}$ & 50 & 0.71 & 40 & - & $\sim 0.37$ & [7] \\
\hline $\begin{array}{l}\mathrm{Pt} \text { NWs/SL- } \\
\mathrm{Ni}(\mathrm{OH}) 2\end{array}$ & $95 @ 5 \mathrm{~mA} \mathrm{~cm} \mathrm{~cm}^{-2}$ & 1.96 & - & $\begin{array}{l}16 \mu \mathrm{g} \mathrm{Pt} \\
\mathrm{cm}^{-2}\end{array}$ & $\sim 0.27$ & [8] \\
\hline $\mathrm{Ru} / \mathrm{GLC}$ & 35 & 0.71 & 46 & 400 & $\sim 0.35$ & [9] \\
\hline $\mathrm{Ru} @ \mathrm{CN}$ & 22 & 0.71 & 30 & 0.285 & $\sim 0.39$ & [10] \\
\hline $\mathrm{NiAu} / \mathrm{Au}$ & 36 & 0.71 & 46 & 0.204 & - & [11] \\
\hline CoNi@NC & 142 & 1.96 & 105 & 0.32 & - & [12] \\
\hline $\mathrm{Ag}_{2} \mathrm{~S} / \mathrm{Ag}$ & 199 & 0.71 & 102 & 1.06 & $\begin{array}{c}0.026 @ 25 \\
0 \mathrm{mV}\end{array}$ & [13] \\
\hline $\mathrm{Fe}_{2} \mathrm{P} / \mathrm{C}$ & 115 & - & 56 & 0.72 & - & [14] \\
\hline $\mathrm{Rh}-\mathrm{MoS}_{2}$ & 50 & 0.17 & 24 & 0.31 & $\sim 0.93$ & [15] \\
\hline
\end{tabular}

${ }^{a}$ Only the mass activity of catalysts containing noble metal was calculated at the fixed overpotential (50 mV vs. RHE). The mass activity was not given in most of the listed literature and was calculated by dividing the estimated current (or current density) by catalyst mass (or mass loading). 


\section{References}

[1] a) G. Kresse, J. Furthmüller, Phys. Rev. B 1996, 54, 11169; b) G. Kresse, J. Hafner, J. Phys. Condens. Matter 1994, 6, 8245; c) P. E. Blöchl, Phys. Rev B. 1994, 50, 17953.

[2] J. P. Perdew, K. Burke, M. Ernzerhof, Phys. Rev. Lett. 1996, 77, 3865.

[3] B. Hammer, L. B. Hansen, J. K. Nørskov, Phys. Rev. B 1999, 59, 7413.

[4] H. J. Monkhorst, J. D. Pack, Phys. Rev. B 1976, 13, 5188.

[5] J. K. Nørskov, J. Rossmeisl, A. Logadottir, L. Lindqvist, J. R. Kitchin, T. Bligaard, H. Jonsson, J. Phys. Chem. B 2004, 108, 17886-17892.

[6] S. Anantharaj, P. E. Karthik, B. Subramanian, S. Kundu, ACS Catal. 2016, 6, 4660-4672.

[7] X. Huang, Z. Zeng, S. Bao, M. Wang, X. Qi, Z. Fan, H. Zhang, Nat. Commun. 2013, 4, 1444.

[8] H. Yin, S. Zhao, K. Zhao, A. Muqsit, H. Tang, L. Chang, H. Zhao, Y. Gao, Z. Tang, Nat. Commun. 2015, 6, 6430 .

[9] Z. Chen, J. Lu, Y. Ai, Y. Ji, T. Adschiri, L. Wan, ACS Appl. Mater. Interfaces 2016, 8, 35132-35137.

[10] J. Mahmood, F. Li, S.-M. Jung, M. S. Okyay, I. Ahmad, S.-J. Kim, N. Park, H. Y. Jeong, J.-B. Baek, Nat Nanotechnol. 2017, 12, 441.

[11] Y. Shi, J. Wang, C. Wang, T.-T. Zhai, W.-J. Bao, J.-J. Xu, X.-H. Xia, H.-Y. Chen, J. Am. Chem. Soc 2015, 137, 7365-7370.

[12] J. Deng, P. Ren, D. Deng, X. Bao, Angew. Chem. Int. Ed. 2015, 54, 2100-2104.

[13] M. Basu, R. Nazir, C. Mahala, P. Fageria, S. Chaudhary, S. Gangopadhyay, S. Pande, Langmuir 2017, 33, 3178-3186.

[14] X. Zhu, M. Liu, Y. Liu, R. Chen, Z. Nie, J. Li, S. Yao, J. Mater. Chem. A 2016, 4, 89748977.

[15] Y. Cheng, S. Lu, F. Liao, L. Liu, Y. Li, M. Shao, Adv. Funct. Mater. 2017, 27, 1700359. 